\title{
CAMINHADA ECO-LITERÁRIA EM CABO VERDE ${ }^{1}$
}

\author{
ECO-LITERARY WALK IN CAPE VERDE
}

Avani Souza Silva ${ }^{2}$

\section{RESUMO}

Turistas podem ser atraídos em Cabo Verde pelas manifestações artístico-culturais, ritmos e danças, culinária, esportes náuticos, e pela variada beleza da flora, fauna marítima e transparência das águas. Na Ilha de Santiago, o Mercado de Sucupira nos convida a passeios e compras, e o silêncio do Tarrafal, hoje Museu da Resistência, antigo campo de concentração para africanos nacionalistas e portugueses antifascistas, opositores do Estado Novo, chama a nossa atenção. Propomos analisar como a literatura cabo-verdiana constrói a identidade cultural e, assim, ajuda a promover um turismo cultural consciente: ou seja, por onde o turista passar em caminhadas ecológicas, lembranças da literatura irão pontuar seu caminho. Romances: Chiquinho, Flagelados do vento leste, Hora di bai.

Palavras-chaves: turismo eco-literário; literatura cabo-verdiana; literatura e turismo, caminhada ecoliterária.

\section{ABSTRACT}

There are many reasons for tourists to be attracted by Cape Verde: its artistic and cultural manifestations, rhythms and dances, traditional dishes, nautical sports, the varied beauty of flora, marine fauna as well as the crystal sea water. On the Island of Santiago, the Sucupira Market invites us to sightseeing tours and shopping, while the calm Tarrafal, converted into the Resistance Museum, also calls our attention. The museum was a former concentration camp for African nationalists and Portuguese antifascists and opponents to the Estado Novo dictatorship. We propose to analyse Cape Verdean literature in the way it builds cultural identity. In doing so, it also helps to develop a sustainable cultural tourism: at each step, ecological hiking can bring about memories of literature. Novels: Chiquinho, Flagellates of the east wind, Hora di bai.

Keywords: eco-literary tourism; Cape Verdean literature; literature and tourism; eco-literary walk.

\footnotetext{
${ }^{1}$ Artigo escrito em português de Moçambique.

2 Doutora e mestra pelo Programa de Pós-Graduação em Estudos Comparados das Literaturas de Língua Portuguesa pela Universidade de São Paulo - USP. Graduada em Letras e Licenciada em Língua Portuguesa e Literaturas Brasileira e Portuguesa pela mesma universidade. E-mail: avanissilva@yahoo.com.br
} 


\section{Revista \\ Debates Insubmissos}

\section{INTRODUÇÃO}

Inicialmente, faremos uma abordagem turística do arquipélago, em seus aspectos mais conhecidos ou por conhecer. Quando somos turistas e traçamos um plano de viagem, consideramos lugares bonitos e agradáveis que possam nos atrair por vários aspectos, tanto geográficos, quanto culturais e históricos. Desses pontos de vista, podemos ser atraídos por espaços tais como: praias, montes, ruelas, casarios, montanhas, rios, recantos, museus, culinária, música, artesanato e mercados em geral (de frutas, roupas, lembranças). Em Cabo Verde, pensamos nas festas tradicionais (Colá São João, Festa das Bandeiras, Carnaval, Festa de Santo André etc.), na culinária típica (a cachupa, a cavala frita, as batancas, fongos, cuscus etc.), na bebida nacional (vinho da ilha do Fogo, grogue - feito à base da cana-de-açúcar), nas manifestações culturais como o batuque e o seu ápice (o torno), nas danças e ritmos musicais identitários (morna, funaná, coladeira, finaçon), nos encontros musicais, shows, bailes e pontos de encontro da juventude animados com violões, rabecas e instrumentos de percussão.

Pensamos no Mercado de Sucupira, na Capital do Arquipélago, onde é possível encontrar de tudo: peixes frescos, frutas, comidas, bebidas tradicionais, roupas e calçados, lembranças e artesanato. Podemos programar uma visita à Academia Cabo-verdiana de Letras, à Livraria Nhô Eugénio, à Biblioteca Nacional, ao Centro Cultural Brasil - Cabo Verde, ao IILP - Instituto Internacional da Língua Portuguesa, ao Arquivo Histórico Nacional ou à Fundação Amílcar Cabral, que homenageia o líder nacionalista cabo-verdiano-guineense que lutou pela Independência de Cabo Verde e da Guiné-Bissau, sendo assassinado por traição de um companheiro que se aliou ao governo colonial português. Imperiosa é uma parada no Café Sofia, no Plateau, onde tem cadeira cativa o poeta Arménio Vieira, primeiro escritor cabo-verdiano a ser galardoado com o Prêmio Camões, o mais importante prêmio literário em Língua Portuguesa.

Uma tarde na Cidade Velha, tombada pela UNESCO como Patrimônio Mundial da Humanidade, e localizada no Conselho da Ribeira Grande de Santiago, é um passeio muito agradável, em que podemos ter uma vista privilegiada do mar e da Cidade Velha a partir do Farol de São Filipe. O centro histórico da Ribeira Grande data de finais do século XV e é um marco da presença colonial europeia na África, bem como da história da escravatura. Até o final da escravatura, em 1876, Cabo Verde foi um entreposto de escravizados que se destinavam à Europa 
e às Américas, tendo como um ponto importante de venda o padrão no centro da Cidade Velha, como uma silenciosa denúncia.

A cidade da Ribeira Grande, rebatizada Cidade Velha, no final do século XVIII, constitui a primeira cidade colonial construída nos trópicos pelos europeus. Estabelecida a 15 quilômetros do centro da Praia, ainda conserva seu traçado urbano original e espaços, de que se destacam duas igrejas, uma fortaleza real e a praça do Pelourinho com sua coluna de mármore de estilo manuelino.

Graças à inclusão da Cidade Velha no rol dos patrimônios mundiais tombados pela UNESCO, Cabo Verde está na rota do turismo histórico que, aliado ao turismo de esportes náuticos e ecológico, atrai significado número de visitantes. Em 2018, a morna, gênero musical identitário cabo-verdiano, conhecida mundialmente por intermédio da voz de Cesária Évora, foi apresentada à UNESCO como candidata ao título de patrimônio imaterial da Humanidade.

Uma particularidade na Cidade Velha é a Rua de Bananas, que fica muito próxima à Igreja Nossa Senhora do Rosário. A rua é assim chamada porque tem muitos pés de bananas. Parece uma rua campestre europeia, o piso é de pedras colocadas e fincadas em areia, e as casas também são de pedras, com o telhado em palha. Geralmente portas e janelas são pintadas de cores garridas, como o verde, o vermelho, o azul cobalto. Uma particularidade nessa rua é que na frente da maioria das casas há um vaso ou uma jardineira com um pé de babosa. Para os cabo-verdianos a babosa é uma planta poderosa: espanta os inimigos espirituais.

Outras freguesias há em Santiago, como o Conselho de Santa Catarina, em que o crioulo lá falado é o crioulo fundo, um crioulo familiar, distinto. Trata-se de uma região cujos usos e costumes mais tradicionais são mais perceptíveis na cultura. Santiago, das ilhas, é a mais negra, devido à escravatura, e a que mais se assemelha culturalmente ao continente africano.

Conhecer a antiga prisão do Tarrafal, na Ilha de Santiago, em funcionamento de 1936 a 1954, como campo de concentração para os nacionalistas africanos e antifascistas portugueses, opositores da política do Estado Novo. Dentre os mais de cem angolanos presos, destacam-se os escritores Luandino Vieira, Mendes de Carvalho, António Cardoso e António Jacinto, todos do quadro do MPLA - Movimento pela Libertação de Angola. O Tarrafal, como patrimônio da 


\section{Revista \\ Debates Insubmissos}

Humanidade, transformou-se no Museu da Resistência. Na literatura cabo-verdiana há diversas referências à prisão do Tarrafal, inclusive no romance A hora de bai, do qual trataremos mais adiante.

Não faltam belezas para serem vistas na Ilha do Fogo, com seu vulcão de 2829 metros, suas plantações de uvas nas lavas dos vales, em que alguns ainda conservam o calor das profundezas da terra. Essa ilha produz um bom vinho, muito apreciado pelos turistas. Imperdível é uma visita a Aguadinha, em São Filipe, capital da Ilha.

Uma visita é imperiosa à Ilha Brava, conhecida como Ilha das Flores, terra natal do grande poeta Eugénio Tavares (Nhô Eugénio), em cuja Fundação que leva seu nome é possível conhecer mais sobre a vida e obra do poeta. Uma das vilas da Ilha, Nova Sintra, é considerada a mais linda do arquipélago, sendo suas casas muito floridas, com jardins e hortas. Também merecem destaque as ilhas agrícolas como São Nicolau e Santo Antão; o cosmopolitismo de São Vicente - a cidade mais europeia do arquipélago; a singularidade da produção de sal na Ilha de mesmo nome, o mais novo destino de escritores, pesquisadores e intelectuais para o Festival de Literatura-mundo do Sal que acontece nessa ilha; o deserto da Ilha de Santa Luzia, desabitada por falta de água; a rede hoteleira e de resorts na ilha de Boa Vista, bem como o bairro de papelão, material em que são construídas muitas habitações nessa ilha; a Ilha do Maio com suas águas verdes e cristalinas, e rica gastronomia. Maio, Sal e Boa Vista são as ilhas mais planas do arquipélago.

Poderíamos discorrer ainda sobre as belezas geográficas e culturais de Cabo Verde, e especialmente sobre sua rica e variada gastronomia, mas após feita essa introdução turística geral, passamos a apresentar o arquipélago em seus aspectos culturais, para em seguida determo-nos em seus aspectos literários e identitários.

\section{CABO VERDE: HISTÓRIA E CULTURA}

Ao ser descoberta pelos portugueses no início do século XIV, Cabo verde era desprovida de população e de animais, sendo que havia algumas espécies de aves migratórias. Assim, a povoação do arquipélago deu-se pouco a pouco, ilha a ilha, com povos europeus (portugueses, 
espanhóis, italianos) e especialmente com povos arrancados da Costa da Guiné, notadamente de Cacheu, Geba e Bissau e escravizados. A última ilha a ser povoada foi a ilha de São Vicente, no início do século XIX.

As principais etnias provenientes da Costa da Guiné foram as seguintes, de acordo com António Carreira (1984): forros, mandingas, falupes, pepeis (ou papeis), manjacos, cassangas. Manuel Veiga, com base em estudos do Padre António, acrescenta as seguintes etnias: balantas, bijagós, beafadas, quissis, brâmes, banhuns, fulas, jalofos, bambara, bololas e manjacos (VEIGA, apud SILVA, 2015, p. 46). Manuel Ferreira acrescenta a esse contingente escravizados egressos do Senegal, Benin, Gorea, sudaneses e bantos (FERREIRA, 1973, p. 41).

A essas etnias somam-se ainda outras referidas pelos Boletins Culturais da Guiné Portuguesa, publicados pelo Centro de Estudos da Guiné Portuguesa: baiotes, mancanhas, sôssos e nalús, perfazendo mais de 20 diferentes etnias que foram levadas para Cabo Verde. No entanto, da população negra que povoou o Arquipélago, não houve apenas escravizados, mas também negros livres, como os banhuns, cassangas e brâmes que acompanhavam espontaneamente mercenários e capitães de navios, e muitos deles falavam o português, sendo que alguns aportaram à Ilha de Santiago para serem cristianizados (SILVA, 2015, p. 46).

Devido à posição geoestratégica de Cabo Verde, favorecendo o comércio triangular entre Europa, África e América, o arquipélago, com sede na Ilha de Santiago, transforma-se num entreposto de escravizados, que saem fundamentalmente da Costa da Guiné, mas também de Dacar, Gâmbia, Conacri e Serra Leoa. (Hernandez, 2002, p. 39). Depois de ladinizados, esses escravizados são exportados para diferentes destinos, dentre eles Antilhas, Cartagena, Honduras, Caracas, Pará e Maranhão. António Carreira dá como segura a existência de uma corrente de escravatura entre as Antilhas e Cabo Verde (CARREIRA, 1972). Esse intercâmbio étnico e cultural poderá estar, segundo Vasco Martins (1989), na base das ressonâncias afro-americanas-caribenhas na música e dança cabo-verdianas, importantes vetores da identidade cultural do arquipélago.

Dentre as então colônias portuguesas, Cabo Verde foi a que mais se hibridizou culturalmente e se mestiçou biologicamente, especialmente com europeus, resultando em uma sociedade mestiça nos trópicos. Daí porque seus produtos culturais remetem à metrópole tais 
como utensílios domésticos, vestuário, culinária, música, literatura etc. e a língua crioula, surgida do contato entre línguas de matriz africana e o português falado pelos metropolitanos.

A multiplicidade étnica no Arquipélago, a convivência com os europeus e, principalmente, a união popular para fazer frente aos ataques dos corsários franceses e ingleses, empreendendo fugas para as montanhas, são razões que favoreceram a mestiçagem biológica e cultural.

Os jogos de ouri, tipicamente africano, o batuque e outras manifestações artísticas, a culinária, a música, as narrativas orais, os provérbios, adivinhas, fábulas, contos e lendas, os jogos e canções infantis, bem como a Literatura, dialogam com os universos culturais africanos e europeus, fazendo com que a vida cultural de Cabo Verde seja muito rica e diversificada. Os ataques dos piratas, por exemplo, incentivaram o surgimento de brincadeiras e de canções infantis.

A criança cabo-verdiana participa ativamente da vida comunitária, seja em momentos de alegria (festas e manifestações culturais), seja em momentos de tristeza (doenças, velórios e enterros), e é ouvinte privilegiado das estórias que povoam o imaginário crioulo, as quais formam verdadeiros ciclos de narrativas: do Boi, do Lobo (Ti Lobo, tio lobo), da Sirena (sereia), dos pateados (encantados saídos de outras ilhas distantes no meio do mar e atravessam a Ilha de São Nicolau, em noites de luar, em cavalgadas ruidosas, com grande cantoria); das bruxas e feiticeiras, e demais seres maravilhosos chamados "côsa runhe" (coisa ruim), como o Gongon (fantasma ou bicho papão também chamado de Gangão, Gongon, Gongunhana), Catchorrona, Luzona, Capotona, Bejons, Xuxo, Cutumbembém etc. Há também um universo significativo de narrativas com elementos do sobrenatural como o homem do chapéu de Panamá, homem do pé de cabra, o feiticeiro de Santo Antão e outras.

As estórias são contadas no início da noite, porque acredita-se que se contadas durante o dia cairiam as pestanas. Reúnem-se a família, parentes e vizinhos em frente às casas ou na cozinha. Atualmente, esses encontros são mais raros, a não ser no interior das ilhas, devido aos interesses da meninada e dos jovens por jogos eletrônicos e mídias digitais. O herói das crianças cabo-verdianas é Ti Lobo (tio lobo), um lobo glutão e cheio de artimanhas, tocador de tambor e apreciador de música, que vive se metendo em enrascadas para matar sua fome atávica. Ele 


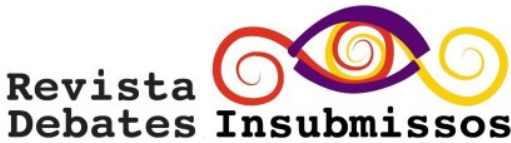

protagoniza aventuras com Xibinho, seu sobrinho, ou Pedro, seu compadre. Uma singularidade de Ti Lobo que o torna mais engraçado para as crianças é que ele fala errado, trocando fonemas.

Cabo Verde é um país de clima semi-árido, situado na rota do Sahel, recebendo em consequências os ventos alíseos, quentes e poeirentos, que carregam para o ar as nuvens de chuvas, impondo grandes períodos de seca ao arquipélago resultando em fome, mortes, pestes, ataques de gafanhotos e pragas. Esses períodos de seca e de fome eram longos, acarretando muitas mortes de que destacamos a seca de 1941-1943, que ceifou 37.000 vidas.

A literatura cabo-verdiana trouxe as marcas da fome, da insularidade; do desejo de ter de ir querendo ficar ou ter de ficar querendo ir que caracterizou um movimento literário intitulado Evasionismo, e depois o Terralongismo (refletindo sobre a terra-longe, expressão que designa o lócus emigratório); o Pasargadismo (referindo-se à fuga para um lugar idílico e imaginário poetizado pelo brasileiro Manuel Bandeira) e outros movimentos literários anteriores inspirados no proto-nacionalismo, no Nativismo, no Modernismo Brasileiro e Neo-realismo português, além de outros movimentos literários regionais sucessivos.

Destacamos que hoje Cabo Verde, com a dessalinização da água, o reflorestamento, os cuidados hídricos, a preservação ambiental, investimentos em infraestrutura, e graças à ajuda de sua diáspora americana com a remessa de dólares para as famílias, o país deixou para o passado esses ciclos de morte, e é hoje considerado como uma das melhores governanças econômicas dos países africanos.

Pontuamos que o tema da fome e suas diversas interfaces históricas, políticas, geográficas, geopolíticas, econômicas, sociais e culturais são abordados com muito cuidado pelo estudioso brasileiro, médico e nutrólogo, Josué de Castro em obras emblemáticas: Geografia da fome (1946) e Geopolítica da fome (1962). Em 1951, Josué de Castro foi eleito Presidente do Conselho da Food and Agricultural Organization (FAO). Atualmente, eleito por duas vezes seguidas e com mandato até 2019, um brasileiro, José Graziano da Silva, é o diretor-geral da Organização das Nações Unidas para a Agricultura e Alimentação (FAO). A fome é um tema muito próximo do povo brasileiro, e também foi abordada em romances emblemáticos como Vidas Secas (1938) de Graciliano Ramos, e O quinze (1930) de Rachel de Queiroz. 


\section{A LITERATURA CABO-VERDIANA E A IDENTIDADE CULTURAL CRIOULA}

No tocante à literatura cabo-verdiana, o tema da fome foi imortalizado em romances considerados clássicos: Chiquinho (1947), de Baltasar Lopes; Os flagelados do vento leste (1959), de Manuel Lopes, Famintos (1962) de Luís Romano, e Hora di bai (1962), de Manuel Ferreira. Este último título, em crioulo, significa em português Hora da Partida, e é uma referência à uma morna, ritmo identitário cabo-verdiano, de autoria do poeta bravense Eugénio Tavares.

Tanto a cultura quanto a Literatura e demais aspectos da vida crioula, como as tradições orais, o patrimônio material e imaterial, usos, costumes, e o próprio imaginário, são constitutivos da identidade cultural do povo cabo-verdiano. Maffessoli (2001, p. 75). Considera o imaginário como a própria cultura, enquanto seu mestre, Gilbert Durand, o considera como "o conjunto de imagens que constitui o capital pensado do homo sapiens, [aparecendo-lhe] como o grande denominador fundamental onde se vêm encontrar todas as criações do pensamento humano" (Durand, 2001, p. 18). Por isso, sendo a imaginário a própria cultura e sendo ele ao mesmo tempo integrante da cultura, podemos considera-lo como indissociável dos processos culturais, sabendo de antemão que a cultura alimenta o imaginário, e este é retroalimentado por ela.

Para Maffessoli, a cultura é um conjunto de elementos e de fenômenos passíveis de descrição, podendo ser considerada como o estado de espírito que caracteriza um povo (Maffesoli, 2001, p. 75). Se podemos descrever elementos e fenômenos que compõem a cultura, podemos também detectar nesses elementos e fenômenos diálogos com outras culturas. Assim, tanto a cultura, quanto o imaginário, sendo este aquela, constroem a identidade cultural de um povo.

Temos presente que, no mundo moderno, as culturas nacionais constituem-se nas principais fontes da identidade cultural. Para Stuart Hall, as culturas nacionais produzem sentidos sobre a nação, sentidos estes com os quais podemos nos identificar e que produzem identidades. Para Hall, "esses sentidos estão contidos nas estórias que são contadas sobre a nação, memórias que conectam seu presente com seu passado e imagens que dela são construídas” (2006, p. 51). Essa concepção ratifica a intencionalidade de fortalecimento da identidade cultural cabo-verdiana presente na Literatura como um dos postulados da cabo-verdianidade: movimento literário e cultural de afirmação identitária, de cunho regionalista, de que a Claridade - Revista de Arte e 


\section{Revista \\ Debates Insubmissos}

Letras, ou simplesmente Claridade, cujo primeiro número data de 1936, foi originalmente o portavoz, divulgando a cultura, a Literatura e a língua crioula.

Stuart Hall também destaca o caráter não fixo da identidade cultural, sendo que ela está em constante processo de construção em razão das interações socioculturais e do intercâmbio econômico e cultural no mundo globalizado. Para o sociólogo jamaicano, uma nação não é apenas uma entidade política, mas uma comunidade simbólica, "algo que produz sentidos - um sistema de representação cultural. As pessoas [...] participam da ideia de nação tal como representada em sua cultura nacional” (HALL, 2006, p. 49).

Assim, as culturas nacionais são compostas não apenas de instituições culturais, mas também de símbolos e representações. Pontifica Hall: "Uma cultura nacional é um discurso um modo de construir sentidos que influencia e organiza tanto nossas ações quanto a concepção que temos de nós" (HALL, 2006, p. 50). Por isso, ao produzir sentidos sobre a nação, as culturas nacionais, com base no processo de identificação, constroem identidades. Esse entendimento converge para o de Boaventura Sousa Santos de que a identidade é uma identificação em processo, em curso ou em andamento, pois sofre modificações que de tempos em tempos se corporificam e aparecem (SANTOS, 1999, p. 119).

Do mesmo modo que a identidade pessoal, a identidade cultural sofre impactos do processo de globalização, fenômeno econômico e cultural de trânsito transnacional de bens, pessoas e serviços, que interfere na vida e nas culturas, deslocando as identidades. Por isso, não há como se estudar a identidade sem ter em consideração os impactos da globalização ou mundialização da cultura sobre ela. Vincula-se à identidade cultural a memória histórica dos grupos ou sociedades em constante contato cultural com outros grupos e sociedades e com suas respectivas culturas que dinamizam o seu processo de crescimento e de desenvolvimento.

Para Baumann (2005) a identidade é fluida, líquida, permeável, o que converge para a constatação de Hall de que ela se torna "celebração móvel": "formada e transformada continuamente em relação às formas pelas quais somos apresentados ou interpelados nos sistemas culturais que nos rodeiam" (Hall, 2003, p. 13). O sociólogo jamaicano lembra ainda que a 
Revista

Debates Insubmissos

identidade é formada historicamente, e não biologicamente. Essas afirmações nos aproximam da concepção de identidade de Édouard Glissant neste mundo de crioulização:

Penso que chegamos a um momento da vida das humanidades em que o ser humano começa a aceitar a ideia de que ele mesmo está em perpétuo processo. Ele não é ser, mas "sendo" e que como todo "sendo", muda. [...] um dia vamos admitir que não somos uma entidade absoluta, mas sim um sendo mutável (Glissant, 2005, p. 33, aspas nossas).

Feitas essas considerações, percebemos que a Literatura é um grande vetor da identidade cultural. E no caso específico de Cabo Verde, em que ela se realiza majoritariamente em língua portuguesa, trazendo termos crioulos para o espaço literário, é uma grande transmissora da cultura e da difusão do cotidiano crioulo, resgatado para o contexto ficcional e poético. E aqui, consideramos também as narrativas orais como sendo Literatura, em sentido amplo, porque construídas na oralidade com engenhosidade e complexidade, ou seja, com engenho e arte, como já sublinhou Walter Ong (1998), em importante trabalho sobre o tema. Nesse sentido, o rico manancial de narrativas orais crioulas fortalecem a identidade cultural, como de resto todas as interfaces do patrimônio material e imaterial crioulo, incluindo as tradições orais, presentes nos romances citados, de que destacamos, pela sua singularidade o seguinte esconjuro "Figas, canhoto, mar de Espanha, beldroegas, rabo de gato preto...”(LOPES, 1986, p. 13).

\section{LITERATURA E TURISMO}

Acreditamos que uma viagem turística a Cabo Verde deve passar necessariamente pelo conhecimento prévio de sua história e cultura, e especialmente de sua Literatura, para que a viagem resulte em uma imersão intercultural plena de significados. Por isso indicamos, como leituras primeiras, os grandes clássicos da literatura cabo-verdiana: os romances Chiquinho, Os flagelados do vento leste e Hora di bai.

Os romances são ambientados nas ilhas agrícolas de Santo Nicolau (Chiquinho), Santo Antão (Os flagelados do vento leste) e na ilha cosmopolita de São Vicente, papel que conquistou graças a intercâmbios culturais com estrangeiros dos navios que lá aportavam, no Porto Grande, para abastecimento em viagens às Américas e à Europa. Em meados do século passado, o Porto Grande entrou em decadência, perdendo espaço para os portos de Dakar e de Las Palmas, 
comprometendo a economia do arquipélago. Mindelo, capital da ilha de São Vicente, será o cenário do romance Hora di bai.

Como já dissemos anteriormente, a escolha dessas obras para propor turismo eco-literário fundamenta-se na importância delas no sistema literário cabo-verdiano, e também na singularidade das ilhas que figuram como espaço ficcional, especialmente São Nicolau e Santo Antão. Acreditamos que o desenvolvimento de um turismo literário sustentável pode gerar condições sócio-econômicas melhores para as Ilhas, além de promover a literatura do país, pouco conhecida, inclusive no Brasil, em virtude das dificuldades de edição e distribuição das obras. Naturalmente, o país conta com excelentes escritores e poetas contemporâneos, e também antigos, com obras de muita relevância no contexto das literaturas africanas de língua portuguesa, e a escolha das três obras citadas não exclui outros autores que utilizam espaços ficcionais de outras ilhas.

\subsection{Chiquinho, de Baltasar Lopes}

Chiquinho é um romance de formação (bildungsroman), em que a vida do protagonista é enfocada de sua infância até a idade adulta, quando parte para os Estados Unidos, seguindo o caminho da emigração imposta pela seca e pela miséria, caminho esse já percorrido por seu pai que no tempo diegético do romance ainda se encontrava naquele país. O romance é dividido em três partes, cada qual relacionada a um período de vida do protagonista: a infância em São Nicolau, a juventude estudando em São Vicente, e o retorno a Santo Antão, como professor e a posterior emigração.

A obra é considerada o primeiro romance moderno cabo-verdiano, e por nós é tido como a primeira obra infantil e juvenil cabo-verdiana. Embora não escrito especialmente para crianças e jovens, a obra tem muita ressonância nesse público leitor e até hoje é considerada, pela juventude crioula e pelos leitores adultos, como o melhor romance de todos os tempos. Não faltam personagens interessantes e muito ligados à terra e à contação de histórias, fio condutor da primeira parte do romance. Os seres maravilhosos que povoam o imaginário crioulo surgem na narrativa formando novas narrativas, num contar quase que ininterrupto. Temas como a seca, a morte, a religião (Racionalismo Cristão, de origem brasileira), as chuvas, pragas, agricultura, alcoolismo, bruxas e feiticeiras, mornas, seres encantados ou maravilhosos, sonhos, descoberta 


\section{Revista \\ Debates Insubmissos}

do amor e decepções povoam todo o romance, atraindo crianças e jovens, não só adultos. O tema central do romance divide-se entre a fome e a morte que tanto abalam Chiquinho, especialmente quando se tratam de seus alunos, e a contação de estórias, traço marcante da cultura crioula:

[Tói Mulato] referia-nos que Nhô João Joana lhe contou que, no princípio do mundo, a Terra era uma mulher muito bonita e muito infeliz. Vendo os seus filhos morrer por falta de comida, saía todas as noites a vaguear e ia chorar nos cumes das rochas os seus amores perdidos. Ela tinha-se casado com um moço leviano que nunca lhe aparecia inteiro, mas sim partido em pinguinhos de água. A Terra ficava sempre com gana do amor incompleto do seu marido. E este saía pouco depois, a visitar as mãos de filho que tinha por esse mundo fora (Lopes, 1986, p. 19-20).

As estórias sucediam-se pungentes, às vezes contadas pela mãe, por Mamãe Velha (a avó), por Nhô Chic'Ana, por Tói Mulato, por Nhá Rosa Calita, "velha pretona a quem os rapazes trocistas chamavam Camões, por lhe faltar um olho em virtude de pau-de-finado" - pó maléfico (p. 12). A criançada se reunia e lhe pedia, utilizando as expressões tradicionais crioulas de início de contação de estórias: "História, história!”, ao que ela respondia: "Fartura do céu, amém!” E principiava: "Era uma vez uma princesa que andava a correr mundo à procura de Passo-Amor, seu noivo, mas para o alcançar tinha de furar a sola a sete sapatos de ferro: “Acorda, Passo Amor/ Há mil léguas em procura de ti...” (Idem, p. 12).

Eram contadas estórias de Carlos Magno, de Ti Lobo e Chibinho (Tio Lobo e seu sobrinho), de fantasmas cangados em pessoas, de gongons, de marinheiros, de sereias, de bebedeiras, de acidentes, da escravatura, de piratas. "O amor era tratado como assunto familiar, sem mistérios nem disfarces. Mesmo as pessoas mais velhas falavam sem reservas na nossa frente de doenças feias, mulheres parideiras, raparigas que tinham sido desonradas e das mães de filho de cada um" (p. 25). As estórias impressionavam vivamente Chiquinho e iam formando sua alma de crioulo e fortalecendo sua identidade cultural, e ao mesmo tempo embalando os seus sonhos e os das demais crianças, aguçando seus olhares para o mundo e a natureza, tratados com poeticidade pelo narrador:

As constelações eram rebanhos pastando. Dávamos nomes de vacas conhecidas às estrelas mais brilhantes. Detrás das estrelas, Nossenhor era um velho pastor vigiando o seu gado. Tínhamos um outro respeito pela Estrada de Santiago. Quando ela estava mais gorda pensávamos na nossa cabeça: "Hoje morreu gente de fome". As pessoas que morriam de fome eram enterradas na Estrada de Santiago (LOPES, 1986, p. 32). 


\section{Revista \\ Debates Insubmissos}

O espaço principal da narrativa da primeira e segunda partes do romance é o Caleijão, mas outros espaços abrigam as ações das personagens na Ilha: a Câmara Municipal, Galhana, Praia dos Garfos, Campo da Preguiça, Boca da Ribeira, Ribeira da Prata. Na Ribeira da Prata, Chiquinho tinha fé de encontrar feiticeiras, mas não as encontrou. No entanto, ficou para sempre "depositado no fundo de sua alma o respeito pelo mistério da Rocha Escrevida, em que há letras inscrita pelos piratas quando desembarcavam aos tiros na praia agreste, atraídos pelos verdes dos canaviais" (p. 33). Nessas ocasiões, o povo fugia para as rochas, e "o vale cantava de tiros estalando", e pedras rolando dos picos em defesa da casinha que ficou lá embaixo. Em viagem a São Nicolau, visitar a Rocha Escrevida, cheia de mistérios, nos chama atenção. Afinal, são inscrições rupestres ou marcas de piratas franceses e ingleses que atacavam as ilhas?

Para Chiquinho, o mar era um campo de batalha em que se lutava com gigantes enormes para se conquistar o amor da moça do mar. E também um mar de estórias dos navios de pesca da baleia, da presença dos capitães que morreram: "Dizem que os navios trazem no cocuruto dos mastros as almas dos capitães que morreram... [...] Quando eu morrer a minha alma ficará espiando do alto dos mastaréus. (...) Ficarei lá para ensinar o caminho aos outros.” (Lopes, 1986, p. 37).

O mar era o destino do povo cabo-verdiano para a emigração, também ele era a fonte de tantas estórias de velhos marinheiros que juravam que no fundo dele havia grandes castelos; muitos se apaixonaram pelas sereias ouvindo seus cantos mágicos e teriam se atirado em seus braços para o nunca mais. Alguns tatuaram sereias em seus braços fortes iludidos pelo amor delas.

São vários os espaços na Ilha, cenário das ações, que nos chamam a atenção, sugerindonos visitas onde for possível, para fruir as obras, cuidando para não cairmos das rochas, como se diz em São Nicolau (e também em Santo Antão): Assomada do Cabaçalinho, onde morava Totone Menga-Menga, personagem real apropriada pela ficção de Baltasar Lopes; Morro Morial, Ribeira dos Calhaus, Lombinho de Cima, Bica da Passagem, Largo da Sé, Pico de Mãe Clara, Selada do Boqueirão, Chãzinha, Paul, Ladeira, Ladeira do Cachaço, Cintinha, Prainha, Estância de Baixo, Canal de Carambola, Morro Brás, Praia Branca, Campo do Norte, Ribeira da Caixa, São João, Rua da Amargura, Cambota, Tabuga (onde foi enterrado Nhô Chic'Ana, que também morreu de fome para desespero de Chiquinho), Lombinho de Cima, Assomada do Mancebo, Fragatinha, Ponta do Focinho, Ladeira, Pedacinho, Chã do Madeiral, Largo da Sé, Lombinho de Cima. 


\section{Revista \\ Debates Insubmissos}

Um espaço importante do romance é o Seminário de São Nicolau, onde Chiquinho estudou os primeiros anos. Já em São Vicente, ele estudou no Liceu, espaço de educação privilegiado e honroso, não acessível, porém, a todos na época da escrita e publicação do romance, nem no tempo diegético da obra. Outros espaços mencionados no romance, que também nos chamam a atenção, estão localizados na Ilha de São Vicente, especialmente no Mindelo, sua capital, onde Chiquinho passou alguns anos de estudo. São eles: Alto de Miramar, Largo da Salina, Câmara Municipal, Ribeira de Julião, Chã do Madeiral, Monte Sossego (onde morava e morreu de fome Parafuso, amigo e aluno de Chiquinho), Fernando Pó, Fontinha, Derbi (salão de baile, posteriormente cinema), Ribeira Bote e bairros populares como Craca e Alto de Selarino. Foi em São Vicente que formou-se professor, e se apaixona por Nuninha, seu primeiro amor, com quem pretende se casar na América.

O romance é rico em informações sobre a fauna, a flora, os costumes, o vestuário, as relações comunitárias, os meios produtivos agro-pecuários, canções, ritmos, lendas, cantigas de trabalho (aboios), cantigas agrícolas, esconjuros, rezas, métodos de cultivo; gêneros musicais (morna, blues, jazz) e instrumentos musicais (viola, cimboa, rebeca, violões, cavaquinhos e tamborins); e também os alimentos com destaque especial para a cachupa, inclusive a guisada. Demais alimentos serão elencados ao final do artigo, uma vez que são referidos praticamente nas três obras.

\subsection{Os Flagelados do Vento Leste, de Manuel Lopes}

Os flagelados do vento leste retratam as situações de extrema pobreza, fome, miséria e abandono da população de Santo Antão em momento de grande crise em razão das secas, agravadas pelo vento leste e por pragas de gafanhotos. O vento leste, também chamado de lestada, harmatão ou suão, é um vento forte, carregado de poeira que vem do deserto do Saara queimando e destruindo toda a vegetação, impondo mais sofrimento ao povo que não têm com o que se alimentar e aos seus animais. O vento leste é um verdadeiro castigo para o povo:

O vento ardente descia das montanhas, como se as portas do Inferno ficassem para esses lados. Varria a superfície dos campos cobertos de verde viçoso. Por onde passava deixava manchas de amarelo-torrado, folhas doiradas dançando nos ares e um cheiro irrespirável a pimenta em pó. Os milharais agitavam-se aflitivamente, como pedindo socorro aos homens. Os feijoeiros e as aboboreiras, desamparados, acenavam os 


\section{Revista \\ Debates Insubmissos}

compridos caules quase despidos de folhas. Estas erram continuamente arrancadas e levadas no turbilhão. Redemoinhos de poeira vermelha dançavam a sua dança de roda, aqui e ali (LOPES, 2001, p. 85)

Vento asfixiante, espalhava sofrimento até nos objetos: "O ar que circulava no interior da casa queimava os lábios, secava as narinas e a garganta doía nos cantos dos olhos. A própria mesa, os bancos, os pés e o esteirado da cama gemiam sob o látego do suão" (p. 97).

O romance retrata a expectativa e a fé religiosa dos cabo-verdianos nas chuvas, especialmente o protagonista, José da Cruz. As chuvas chegam, após a sementeira em pó, mas quando a plantação está ganhando corpo chega o vento leste, que além de queimar tudo carrega as chuvas para o mar, impondo maiores sofrimentos ao povo. As situações retratadas são desesperadoras, pois em momento de extrema penúria e fome, vemos personagens centrais do romance tendo seus filhos mortos de fome, vemos o abandono das casas e o movimento das pessoas para o centro da ilha, onde o governo promete serviços nas estradas.

O romance trata essencialmente dos efeitos devastadores da seca e do vento leste, e como isso interfere na vida do povo ilhéu, impondo destruição, morte e sofrimento, e alimentando o desejo quase impossível da emigração, por absoluta falta de condições estruturais e econômicas. O Vento Leste, Nordeste, Lestada, Harmatão ou Suão, ocupa lugar central na narrativa, como uma personagem, porque é em torno dele e por causa dele que os acontecimentos têm lugar.

O que é mais pungente nos relatos são as carroças da administração passando diariamente para recolher os mortos, tombados de fome dentro das casas ou nas ruas. Muitas vezes, e também no romance Chiquinho, há relatos de que a carroça leva pessoas ainda vivas para enterrá-las, evitando voltar no dia seguinte para recolhê-las de seu impiedoso destino.

A fome obriga os ilhéus a venderem seus utensílios (copos, panelas, talheres), os poucos móveis para queima (no tempo diegético do romance não havia gás, e sim o fogão de três pedras alimentado a madeira retirada dos campos, piorando a situação de aridez); roupas, janelas, portas, telhado, palha do telhado, portões. Enfim, tudo o que fosse possível vender em troca do milho, alimento básico do povo crioulo.

O romance também desnuda os roubos, assaltos e furtos de animais e de alimentos, empreendidos ou pela população faminta ou por salteadores, chamados mascarados porque assim 
se apresentavam nos caminhos dos jornadeiros. Caminhos, diga-se, perigosos, bordeiras estreitas dos planaltos, ladeados de um lado por verdadeiros precipícios de rocha. Esses precipícios tanto em Santo Antão como em São Nicolau, referidos em ambos os romances - Chiquinho e Os flagelados - exigem cuidados e geram ditados: "Destino não é só cair de rocha" (LOPES, 1986, p. 51);

Os caminhos que recortam os planaltos de Santo Antão são percorridos pelos povos das ilhas que moram nos altos, juntamente com seus animais carregados, suas crianças e cachorros. É também caminho de cabras. Esse cenário ainda persiste atualmente em Santo Antão, e turistas chegam a percorrer esses caminhos, em longas caminhadas, porque muito atrativos.

O ponto central do romance é a honestidade, a esperança e a fé em Deus de José da Cruz. E também o amor que une o casal e os filhos, até que a esposa por uma pedra que rolou e a levou rochas abaixo, numa noite em que ela, desesperada, buscava um palito de fósforos do enteado que se fora na noite dentro. Nesse tempo, todos os vizinhos e conhecidos já tinham ido embora, abandonado suas casas em direção à estrada na esperança de obterem serviço do Estado. $\mathrm{O}$ motivo do palito de fósforo, na necessidade que havia, assume uma dimensão ontológica no drama da família. As crianças também morrem. E só José da Cruz como um verdadeiro molambo na cidade, sem forças para se apoiar até que morre. Com a morte posterior de Leandro, toda a família desaparece.

Há muitos relatos feitos pelas personagens sobre acontecimentos da ilha, bem como, do mesmo modo em que ocorre em Chiquinho, estórias de gongons (fantasmas e bichos papões) e de bruxas pontuam o cotidiano diegético. O povo tinha medo de bruxas: "Diziam os velhos que as bruxas podiam dormir cem anos sem acordar" (p. 131); "Dizem que as bruxas têm sete vidas, como os gatos" (p. 183)

Há também uma estória de amor, de primeiro amor, em que o casal vive como bichos, escondidos numa gruta, protegida por grandes rochas. Ele, um mascarado, filho de José da Cruz com a primeira esposa. Ela, uma jovem fugida de casa pela humilhação que sofreu da mãe e da professora por ter roubado desta uma lata de doce. A relação deles é muito afetuosa e mostra um novo caminho a Leandro, portador de uma cicatriz que ia do canto da boca à orelha, um corte 


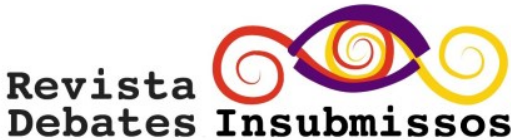

infernal que sofrera por acidente na infância e que vai marcar toda sua trajetória: o medo que as pessoas tinham dele por causa da cicatriz, e a vergonha que ele tinha das pessoas, associado também a forte sentimento de rejeição.

Há nas famílias encontros musicais com os amigos, parentes e vizinhos, em que sempre alguém tocava morna no violão, principiando bailes. Diferentemente de Chiquinho, nesse romance não há quase vozes infantis, mesmo existindo as crianças dos protagonistas. Suas ações limitavam-se a espantar os corvos com estilingadas e esconjuros para que não roubassem os grãos de milhos plantados. A título ilustrativo, citamos as imprecações dirigidas pelas crianças aos corvos, referida no romance Chiquinho, já que ambos os romances tratam desse trabalho executado pelas crianças: "Vai assombrar a tua mãe, maldito! Não tens sombra para ti, quanto mais para dares! (LOPES, 1986, p. 26). Lembramos que "A guarda mais difícil era dos pardais. Para eles de nada serviam pedradas. Tínhamos que correr de uma banda para outra, dando estalos nas fundas" (p. 26).

No tempo diegético do romance, as famílias participavam de todo o processo agrícola: preparação da terra, semeadura e colheita, sendo que as crianças tinham um trabalho muito específico: espantar os corvos e os pardais, o que faziam com pedradas e estilingadas para que aqueles não roubassem os grãos de milho, e estes últimos não comessem os brotinhos.

Uma modalidade agrícola muito singular, adotada em Cabo Verde, referida no romance Os flagelados do vento leste, é o semear em pó. Na expectativa das chuvas e na esperança de que ela estivesse por vir a qualquer momento, observados sinais no céu e consultados lunários perpétuos as famílias dividiam assim o serviço: os homens abriam as covas, as mulheres vinham atrás jogando quatro grãos de milho, e tapando a cova empurrando o montículo de terra com o pé; em seguida vinham as crianças colocando pedras sobre as covas para evitar que os corvos roubassem as sementes.

No romance Os flagelados do vento leste, José da Cruz é o primeiro a sentir que viria chuva e inicia a sementeira em pó. Muitas vezes, as famílias semeiam em pó o único milho que têm para o seu sustento, como foi o caso. O milho começou a brotar e já estava rapazinho quando veio o vento leste destruindo e queimado tudo, e anunciando a fome, a miséria, o abandono e a 


\section{Revista \\ Debates Insubmissos}

morte. Tal como em Chiquinho, há também a infestação de nuvens de gafanhotos que depois de passarem, não deixam rastro de mato nenhum, piorando muito a situação.

"Enxôta corvo" e "enxôta pardal" são cantigas tradicionais, de um rol de cantigas de trabalho (agrícolas, marítimas, de aboio), mencionadas tanto em Os flagelados como em Chiquinho. Também em Os Flagelados há a referência às bruxas e feiticeiras como também aos demais seres sobrenaturais e maravilhosos que povoam o imaginário crioulo, como a capotona (ser arrastando correntes, vestido com um capote preto, assustando as pessoas nos caminhos, durante a madrugada). E, como em São Nicolau, espaço narrativo de Chiquinho, há em Santo Antão também as bordeiras dos planaltos, os grandes picos, precipícios, e rochas, que infundem medo e cuidado nos passantes.

Esses elementos todos sejam as cantigas, o semear em pó, os bailes, a morna, a comida típica, o tipo de habitação (funco: casas de madeira ou pedra cobertas com folhas de palma, em forma de cone), a religiosidade, os ditos, provérbios e sentenças, a observação do tempo, buscando indícios de chuva, o lunar perpétuo, a participação da criança nos trabalhos agrícolas etc. , tudo isso são elementos da cultura crioula que os ilhéus compartilham e com os quais se identificam, fortalecendo a identidade cultural.

As ilhas agrícolas de Santo Antão e São Nicolau fornecem produtos da terra para São Vicente, e isso também é retratado no romance Chiquinho. A visita às ilhas agrícolas e suas plantações de milho, batata, mandioca, papaias, goiabas, tamarindeiros, bananas, abóboras etc. parece-nos um bom passeio, mesmo porque com o contato com o povo da terra podemos ter a chance de provar o grogue de Santo Antão, muito famoso, e provar as comidas deliciosas feitas com os produtos, cultivados de modo sustentável. Sem contar que podemos andar pelas encostas e bordeiras, como os cabo-verdianos, e ainda ouvir estórias que eles contam na boquinha da noite. Sem contar ainda que podemos participar de bailes, festas e ouvir lindas mornas.

Os espaços ficcionais presentes no romance Os flagelados do vento leste, em diálogo com os espaços reais, são os seguintes: Curralete, Ribeirinho Seco, Lombinho, Assomada, Topo da Coroa (a montanha mais alta da ilha), Terranegra, Porto Novo, Chã de Lagoa, Altomira, Ribeira Grande, Garça, Ponta do Sol, Tarrafal de Monte Trigo, Ribeira das Patas, Campo Grande, 
Covoada, Canal, Ribeira do Paul, Ribeira dos Bodes, Cidrão, Ribeira da Cruz, Lajedos, Ribeira da Cruz, Bordeira (borda do planalto), Chã de Morte, Caetano, Curral de Vacas, Chã de Alecrim.

Por fim, apontamos o simbolismo da obra representado pelo olhar poético das personagens às estrelas, como também ocorre no romance Chiquinho. Lembramos que no tempo diegético da obra não havia iluminação, sendo que as pessoas utilizavam óleo de purgueira e, portanto, as noites estreladas e enluaradas eram atrativas e fonte de encantamento, sem contar que o fenômeno das estrelas cadentes era mais perceptível: "As estrelas caiam do céu para os campos, numa saraivada” (p. 192): “(...) as estrelas caíam sobre os campos ressequidos, como flores de cafeeiro batido por um vento reverso...” (LOPES, 2001, p. 195).

\subsection{Hora di bai, de Manuel Lopes}

Romance do português naturalizado cabo-verdiano Manuel Lopes, Hora di bai pertence ao sistema literário (CÂNDIDO, 1975) do Arquipélago, não só pela temática, mas especialmente porque Manuel Lopes esteve sempre integrado à cultura crioula, refletindo essa integração em suas obras, a par do fato de ter vivido no país e se naturalizado, tendo sido casado com a escritora cabo-verdiana Orlanda Amarílis. A obra ensaística e teórica do autor também é vasta, de que destacamos $A$ aventura crioula (1972), referência obrigatória para a compreensão da cultura cabo-verdiana, bem como a organização e prefácio do fac-símile da Revista Claridade-Artes e Letras, reunindo os nove números publicados, de 1936 a 1960. Lembramos que excertos do romance Chiquinho foram inauguralmente publicados no primeiro e terceiro números da Revista, em 1936 e 1937, respectivamente.

O romance $A$ hora de bai (hora da partida) também tematiza a fome que assolou o arquipélago em 1943, e seu título remete à morna de mesmo nome, do poeta bravense Eugénio Tavares, referida no romance, e à partida dos famintos da ilha de São Nicolau para a Ilha de São Vicente. Outras mornas de Eugénio Tavares também são referidas na narrativa, homenageando o poeta.

Há, no romance, três espaços narrativos: a ilha de São Nicolau, o veleiro Senhor das Areias e a Ilha de São Vicente. A fome estava matando muitas pessoas em São Nicolau, e o 


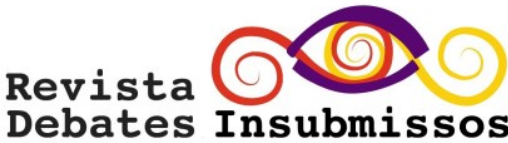

governo mandara buscar pessoas de lá para serem socorridas em Soncente (S. Vicente), desde que estivessem inscritas nas listas de parentes ou aderentes que os tinham convidado.

Os conflitos retratados serão inicialmente no embarque, em que as pessoas famintas tentam de todas as maneiras obterem vaga a bordo, mesmo não estando inscritas. Muitas pessoas famintas tentaram passar-se por outras, durante a chamada, o que exigiu do capitão maior controle das listas com os nomes, mas mesmo assim ele fazia vistas grossas com pena dos famintos, deixando-os embarcar. Depois os conflitos desdobram-se na fome e no mal-estar dos passageiros a bordo, os quais eram recomendados a comer devagar a cachupa oferecida, para não morrerem, pois muitas pessoas morriam por comerem avidamente depois de muito tempo de jejum: "Corpo fraco não aguenta muita comida" (Ferreira, 1980, p. 27). Durante a travessia, houve tocatina de mornas, conversas, assédios sexuais e até um parto de um natimorto que foi lançado ao mar, além de muitas lamentações.

As principais lamentações, recorrentes no romance, na voz de diversas personagens está sintetizada na expressão "Terra nhanhida, Senhor" (terra infeliz, desgraçada). Essas expressões também são ditas no romance Chiquinho por diversas personagens. No entanto, destacamos a coragem, a fé e a esperança do povo cabo-verdiano em dias melhores, traço da personalidade crioula cantada e recantada em prosa e verso, e também marcas dos romances Hora di Bai, Os flagelados do vento leste e Chiquinho.

Em São Vicente, os conflitos e as necessidades persistem, e houve passageiros que morreram logo ao desembarque, como foi o caso de Conchinha (a parturiente) que embarcara sem ter para onde ir e quem pudesse acolhê-la no destino em São Vicente. Temas como os bailes, o cancã, a prostituição de crianças e de mulheres que depois iriam continuar sua vida em Dakar, prisões arbitrárias efetuadas pela PIDE, resgate de prisioneiros no Tarrafal, em Santiago, inveja, adultério, maledicências, alcoolismo, vinganças, serenatas. E também tocatinas utilizando violinos, cavaquinhos, violões, rabecas. A valorização do ensino formal em outras épocas, e seu desprestígio na fome também é enfatizada na voz da personagem Nhô Mochinho, que viera de São Nicolau no veleiro, e que continuava buscando grogue e comida, reagindo a troças e repetindo em diversas ocasiões: "Sou homem de letras. Sou homem de liceu." (Ferreira, 1980, passin) 
O tema dos contratados de São Tomé também é enfatizado na obra. Homens e mulheres se inscreviam para trabalharem nas Roças de Cacau, em São Tomé e Príncipe, onde eram escravizados a troco de comida. Os intermediários desses contratos é que ganhavam com esse negócio. Muitos que se inscreviam, no desespero da fome pois sabiam das condições de escravização nas roças, fugiam e se escondiam no dia do embarque, porque Nhô Eduardinho, quem os contratava, não aceitava a desfeita da desistência do contrato. Há, pois, um grande panorama da sociedade vicentina da metade do século passado, em meio à crise econômica muito grave. Morna muito conhecida na voz de Cesárea Évora, “Caminho para São Tomé”, também é cantada e descrita no romance. São Tomé e Príncipe era conhecida como o terra longe, de gente gentio, gente que comia gente, reproduzindo versos de antiga canção de ninar: "Terra-longe tem gente-gentio, gente-gentio come gente...” (p. 133).

Destaque especial para as mornas e outros ritmos como a coladeira e os bailes com cantadores de mornas com instrumentos musicais identitários (viola, violino, cavaquinho) que animavam a vida mindelense. A ilha vivia em torno da expectativa dos vapores que aportavam no Porto Grande, que nessa época já estava em decadência. Os lugares do Mindelo que figuram no romance, a requerer visita e confronto com a Literatura, são os seguintes: Ponta do Sol, Ribeira Brava, Praça Nova, Pontinha, Fortim d'El Rei, Salina (bairros de lata), Praia da Matiota, Monte Verde e seus precipícios, Ribeira Bota, Lazareto, Ribeira Julião, Paul, Monte Sossego (onde morou e morreu Parafuso, personagem de Chiquinho), Fonte Cônego, Chão de Alecrim, Monte Salamanza e seus penhascos.

Tal como em Chiquinho, no romance Hora di bai há referências a estórias de gon-gon (ou gongon), do Lobo e Chibinho, de Ti Pedro e Sobrinho. E também histórias de morte, dor e sofrimento dos ilhéus, em que muitos perderam toda a sua família para a fome.

\section{A CULINÁRIA DAS ILHAS RETRATADAS NOS ROMANCES}

De consumo democrático, o milho compõe um dos pratos mais tradicionais da culinária cabo-verdiana, a cachupa, perpassando a mesa do pobre e a mesa do rico, de acordo com a quantidade e diversidade de ingredientes que entram no seu preparo. A cachupa rica, geralmente, 


\section{nevitate

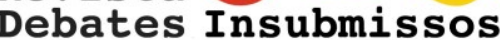

é preparada com milho, feijões, favas, batata-doce, legumes e carnes variadas de porco (chouriços, torresmos e costelinhas) e de frango, além de hortaliças. A cachupa pobre, com milho, sal e banha. Esta última alimentava o povo de Santo Antão em Os flagelados do vento leste e foi servida no veleiro Senhor das Areias, no romance Hora di bai. Rica ou pobre, todavia, ela está presente diariamente na mesa do cabo-verdiano, do menos favorecido ao mais prestigiado, e a diversidade de ingredientes que a classifica dessa forma é indiciadora de diferença social. Alimento mais importante da culinária crioula pode ser servida cozida, com bom caldo, ou guisada (frita depois de cozida).

Como lembra Hopffer Almada (1998, p. 72), a culinária desempenha uma função identitária de tal forma relevante que cabe a um dos pratos - a cachupa - um importante papel na formulação da coesão cultural, por ser comum a todas as ilhas, a todas as classes sociais e a todas as comunidades cabo-verdianas que estejam nas ilhas ou na diáspora. Há também diversos outros pratos da culinária cabo-verdiana que utilizam como ingrediente principal o milho, desde bolos e doces a caldos.

Ainda de acordo Hopffer Almada (1998, p. 78), o milho é considerado "o epicentro" do ciclo da vida do cabo-verdiano e está presente tanto na vida doméstica como intelectual do povo, sendo retratado na música e na literatura, representado nas artes plásticas, no cinema, no teatro e no artesanato, tendo inclusive marcado sua presença na primeira bandeira nacional cabo-verdiana, sendo que a espiga de milho foi depois substituída apenas pela cor do milho.

Além da cachupa (cozida ou guisada), outros pratos feitos à base de milho figuram nos romances em questão, fortalecendo a identidade cultural crioula: a papa, camoca (farinha de milho torrado), o milho aliado (pipoca), a batanca (espécie de broa: bolo achatado feito de fubá e banana), Camoca (farinha de milho torrado) com mel; ovos crus e camoca com mel (para ganhar corpo). E mais: farinha-de-pau (farinha de mandioca) e a talisca que ficava na rala da mandioca com peixe seco da ilha do sal; garoupa cozida; café com farinha-de-pau e torresmos; fonguinho (tipo de pastel de batata e banana); bicuda salgada (peixe seco), sementinhas de fedegosa, potonas (gramídeas), café de ervilha congo, bolo de camoca (farinha de milho torrado), manteiga, queijos, chá de fedegosa (Os flagelados do vento leste) ou fedegosa (Hora di Bai e Chiquinho). Este chá, 


\section{Revista \\ Debates Insubmissos}

feito com as sementinhas do arbusto de mesmo nome, como útimo recurso desesperado à fome, causou inúmeras mortes devido a graves efeitos gastrointestinais.

\section{CONCLUSÃO}

Após breve imersão na história e cultura crioulas, bem como a apresentação das obras, enfatizando seus enredos e espaços narrativos, concluímos que uma viagem turística exige alguns pressupostos que são aconselháveis serem destacados. Primeiro: o conhecimento prévio do país e de sua cultura; Segundo: um conhecimento pelo menos de forma geral de sua Literatura.

Assim munido, o turista que quer conhecer um país, um povo e uma cultura, e não somente apoiar-se em mapa turístico de pontos de interesse geral, deve iniciar esse percurso por intermédio da Literatura. É o que sugerimos neste artigo.

A Literatura, como produto da civilização, tem a finalidade, de acordo com o crítico brasileiro Antonio Candido (1995, 2002), de humanizar as pessoas, satisfazer sua necessidade de ficção manifestada em todos os espaços da vida social (nas estórias contadas, nos casos, nas novelas, filmes, piadas etc), e, além disso, colaborar na formação da personalidade. Por isso a Literatura, importante fonte de fruição artística, fala na alma das pessoas.

Sendo assim, um percurso turístico que vincula um espaço ficcional a um espaço da realidade em que ela foi inspirada, pode ser um caminho para um turismo sustentável, inclusivo e solidário, criando melhores condições sócio-econômicas nas regiões em que acontecem, ao mesmo tempo em que, por intermédio da Literatura e da cultura, fortalece os laços comunitários e a identidade nacional.

Além disso, sabendo que a Literatura antecipa a História, isso nos dá confiança em propor caminhadas eco-literárias, uma vez que essas atividades possibilitam reviver grandes obras por intermédio de seus elementos estruturais, principalmente o espaço, apontando para nós não apenas o passado ficcional, mas experimentando o presente e valorizando o futuro real. Não nos esqueçamos de que as personagens dos romances são ficcionais, mas que, entretanto, foram resultantes de experiências imaginadas a partir do real. 


\section{REFERÊNCIAS}

ALMADA, José Luís Hopffer. O papel do milho na simbolização da identidade cultural do cabo-verdiano. In: VEIGA, Manuel (Org.). Cabo Verde: insularidade e literatura. Paris: Khartala, 1998, p. 63-80.

BAUMAN, Zygmunt. (2005). Identidade - Entrevista a Benedetto Vecchi. Trad. Carlos Alberto Medeiros. Rio de Janeiro, Brasil: Zahar.

CANDIDO, Antonio. (1975). Formação da Literatura Brasileira. 5. ed. V. I. São Paulo: Martins Fontes, Itatiaia.

CANDIDO, Antonio. Direito à literatura. In: CANDIDO, Antonio.Vários escritos. São Paulo: Duas cidades, 1995, p. 235-263.

CANDIDO, Antonio. A literatura e a formação do homem. In: CANDIDO, Antonio. Textos de Intervenção. São Paulo: Duas cidades, Editora 34, 2002, p. 77-120.

CARREIRA, António. Cabo Verde: formação e extinção de uma sociedade escravocrata (1460-1878). Bissau, Guiné-Bissau: Centro de Estudos da Guiné Portuguesa, 1972.

CARREIRA, António. Cabo Verde: Aspectos sociais, secas e fomes do século XX. 2. ed. Lisboa:: Ulmeiro, 1984.

CASTRO, Josué de. Geografia da fome: a fome no Brasil. 2 ed. Rio de Janeiro: O Cruzeiro, 1948.

CASTRO, Josué de. Geopolítica da fome: ensaio sobre os problemas de alimentação e de população. São Paulo: Brasiliense, 1968.

DURAND, Gilbert. As estruturas antropológicas do imaginário. Trad. Hélder Godinho. São Paulo: Martins Fontes, 2001.

FERREIRA, Manuel. A aventura crioula ou Cabo Verde - uma síntese cultural e étnica.

Prefácio de Baltasar Lopes. 2. ed. aumentada. Lisboa: Plátano, 1973.

FERREIRA, Manuel. Hora di bai. (1980). São Paulo: Ática, 1986.

FERREIRA, Manuel. (Org.). Claridade - Revista de Arte e Letras. Edição Facsimilar. Lisboa: ALAC, 1986. 
GLISSANT, Édouard. Introdução a uma poética da diversidade. Trad. Enilce Albergaria Rocha. Juiz de Fora, MG: UFJF, 2005.

HALL, Stuart. Da diáspora - identidades e mediações culturais. Trad. Adelaine La Guardia Resende et al. Belo Horizonte, Brasil: UFMG; Brasília: UNESCO, 2003.

HALL, Stuart. A identidade cultural na pós-modernidade. Trad. Tomaz Tadeu da Silva e Guacira Lopes Louro. 5. ed. Rio de Janeiro: DP\&A, 2006.

HERNANDEZ, Leila Maria Gonçalves Leite. Os filhos da terra do sol: a formação do EstadoNação em Cabo Verde. São Paulo: Summus, 2002.

LOPES, Baltasar. Chiquinho. São Paulo: Ática, 1986.

LOPES FILHO, João. Cabo Verde - retalhos do quotidiano. Lisboa: Caminho, 1995.

LOPES FILHO, João. Contribuição para o estudo da cultura cabo-verdiana. Lisboa: Biblioteca Ulmeiro n ${ }^{\circ} 15,1983$.

LOPES FILHO, João. Introdução à cultura cabo-verdiana. Praia, Cabo Verde: Instituto Superior de Educação, 2003.

LOPES, Manuel. Os flagelados do vento leste. 2. ed, Coleção Palavra Africana. Lisboa: Veja, 2001 .

MAFFESOLI, Michel. O imaginário é uma realidade. Entrevista realizada por Juremir Machado da Silva, Paris, 20.03.2001. Revista FAMECOS, número 15, pp. 74-82, Agosto de 2001. Porto Alegre. Disponível em:

http://revistaseletronicas.pucrs.br/ojs/index.php/revistafamecos/article/viewFile/3123/2395

(Acesso em 10 de outubro de 2019)

MARTINS, Vasco. A música tradicional cabo-verdiana - I. A morna. Praia, Cabo Verde: Direcção-Geral do Patrimônio Cultural/Instituto Caboverdiano do Livro e do Disco, 1989.

ONG, Walter. Oralidade e cultura escrita - a tecnologização da palavra. Tradução de Enid Abreu Dobránszky. Campinas, SP: Papirus, 1998.

OSÓRIO, Osvaldo. Cantigas de trabalho - tradições orais de Cabo Verde. Nota preliminar de Manue Veiga. Lisboa: Plátano, s.d. 
QUEIROZ, Rachel. O quinze. Rio de Janeiro: José Olympio, 2016.

RAMOS, Graciliano. Vidas secas. Rio de Janeiro: Record, 2019.

ROMANO, Luís. Famintos - romance de um povo. Natal: Leitura, 1962.

SANTOS, Boaventura Sousa. Pela mão de Alice - o social e o político na pós-modernidade. 7. ed. Porto: Afrontamento, 1999.

SILVA, Avani Souza. (2015). Narrativas orais, Literatura Infantil e Juvenil e identidade cultural em Cabo Verde. Tese. Universidade de São Paulo. São Paulo. Disponível em: http://www.teses.usp.br/teses/disponiveis/8/8156/tde-05082015-145237/pt-br.php Acesso em 31.10.2019.

Submetido em: 07/11/2019

Aprovado em: 02/12/2019 